\title{
New methods are transforming table olive and olive oil production in California
}

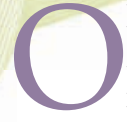
live production is evolving rapidly in California. The state's traditional, laborintensive table olive culture is giving way to super-high-density, mechanically harvested plantings of the fruit for oil.

"The next decade could see California producing a significant amount of the olive oil consumed in the United States," says UC Cooperative Extension (UCCE) farm advisor Paul Vossen, whose work has helped cultivate California olive oil as a unique and growing agricultural market (see page 8 ).

Meanwhile, scientists are closing in on a mechanical harvesting system for table olive trees that could save the industry from being crushed by oppressively expensive hand-labor harvesting costs.

\section{A long and storied history}

Native to the Mediterranean region, olive cultivation began some 7,000 years ago for use as food, a beauty aid, in ceremonies and as fuel. The utility of olives is chronicled in ancient Egyptian hieroglyphics, Greek mythology, the Bible and Quran, Shakespeare's sonnets and innumerable cookbooks, old and new. Today, olives are the most extensively cultivated fruit crop in the world.

In 1769, the first olive cuttings were planted in California at the Mission San Diego. During the 1800s, many small olive plantations existed around the state, but a statewide industry didn't emerge until German immigrant Freda Ehmann of Oroville, working with Professor Eugene Hilgard
Olives are the most extensively cultivated crop in the world. Below, Lucca, a new variety developed at UC Davis, grows in a test plot.

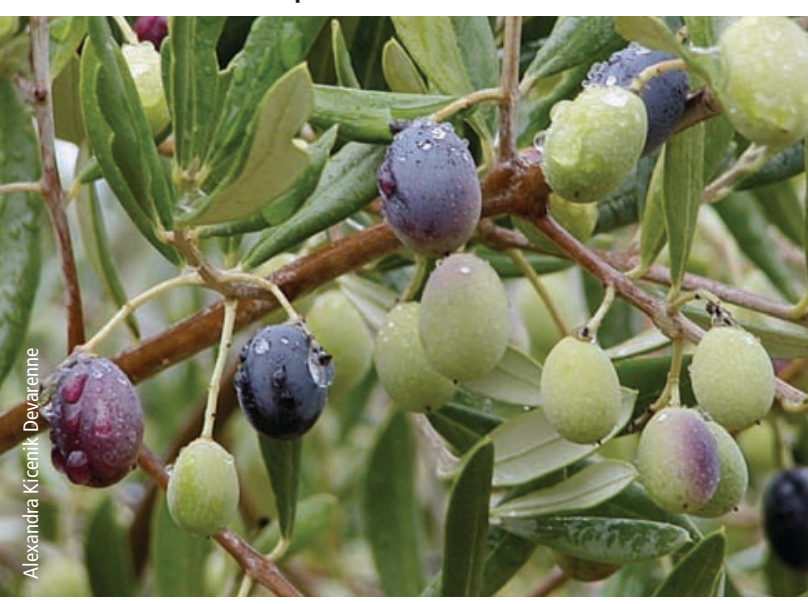
cess at the turn of the century.

Canned black olives (which producers market as "black-ripe" olives) became a quintessential California product. Mild, versatile and meaty, California olives flavor pizza and Mexican dishes and appear on relish trays and in tapenade. Currently, California has about 27,000 acres in table olive production, the bulk in Tulare, Tehama, Glenn and Butte counties.

Canning olive tonnage has declined in the past 5 years, but the price per ton has been steadily improving. In 2006, farmers harvested 123,589 tons of canning olives valued at $\$ 700$ per ton, but in fall
$2009,23,034$ tons were harvested valued at $\$ 1,200$ per ton.

Just two major canneries process California table olives: Bell Carter Olive Company in Corning and Musco Family Olive Company in Tracy. The harvest runs from September to November, with crews climbing ladders to hand-pick the thousands of olives on a typical tree, labor that consumes $45 \%$ to $60 \%$ of table olive producers' gross returns.

UC Davis plant sciences specialist Louise Ferguson is working with a team of farm advisors to develop mechanical harvest methods for table olives, a particularly challenging task because of the high quality standard.

"There is zero tolerance for bruised fruit in the canned product," Ferguson says.

The scientists are studying two options - trunk shaking and canopy contact - but both have problems. With age, the trunks of olive trees become stout, fluted and knobby, which hinders mechanical shaking. Canopy contact is complicated by harvest timing. The fruit must be harvested before it is fully ripe, so significant force is required to remove them from the tree.

"Both methods now produce acceptable olives with about $65 \%$ harvesting efficiency," Ferguson says. "However, with some tree pruning and the development of a suitable conveying and catching platform for the harvesters, I believe that machines could be commercially available in 2 years."

\section{Olive fruit fly}

Olive fruit fly is a severe threat to all California olives. A pest for at least 2,000 years in Mediterranean olive production, it first appeared in California in 1998 and quickly spread to all commercial olive-growing regions in the state (see pages 14, 21 and 29).

The female olive fruit fly lays her eggs in immature fruit. After they hatch, feeding larvae destroy the pulp and introduce microbes that rot the fruit. For table olives, the presence of even a few infested fruit can lead to rejection of the entire crop. Oil olives can tolerate some infestation, as long as the fruit are not rotten.

\section{Super-high-density orchards}

During the last century, most of the olive oil used in California was imported from Spain and 
Italy. Interest in local products, greater awareness about the health benefits of olive oil, and a growing appreciation for fine olive oil's unique flavor has buoyed the California olive oil industry.

In traditional olive orchards, about 50 trees per acre were often planted 30 feet apart, giving them plenty of space to reach their full natural size.

Productive orchards have been maintained in some parts of the world for 100 years or more. But scientists, interested in boosting yield per acre, reducing labor costs and bringing olive plantations into full production quickly, have developed a new, superhigh-density, hedge-row olive production scheme (see page 34). About 10 years ago, Spanish investors planted California's first super-high-density olive plantation near Oroville. The idea took off.

"They've introduced super-high-density all over the world - Chile, Australia, Portugal," says Joe Connell, UCCE farm advisor for Butte County. "The method was developed by a nursery near Barcelona, the largest olive nursery in the world. You can imagine the potential sales for a nursery when producers need more than 600 trees per acre to establish an orchard."

In addition, older olive tree trunks and branches become woody and gnarled, characteristics that will interfere with mechanical harvesting. The super-high-density orchards being established now may have to be removed and replaced in just 15 to 20 years, Connell says.

According to a 2009 UC Davis Olive Center survey, 12,137 acres of super-high-density olive trees were planted in California by the end of 2008, with $92 \%$ of growers reporting that they planted the trees between 2005 and 2008. Many of the plantations are coming into production right now.

Dan Flynn, director of the Olive Center, says California olive oil production numbers are experiencing parallel growth. In 2008, California produced 650,000 gallons of olive oil, and in $2009,800,000$ gallons. In 2010, olive oil production will exceed 1 million gallons. "There's a lot of high quality California oil this year," Flynn says.

"California olive oil will be more readily available around the country."

\section{Developing markets for olive oil}

Developing a market for the oil will be important to the industry's success. Currently, more than $99 \%$ of the olive oil consumed by Americans is imported from other countries. Imported oil is generally cheaper and blander than the oil pressed by California's artisan producers, Flynn says.

In addition, an Olive Center study found that $69 \%$ of the imported oils sampled from California groceries had sensory defects. "This study rocked the olive oil world," Flynn says.
California's young olive oil industry uses up-todate farming and pressing methods to make oils altogether different from European oils, whose producers are following the practices and traditions of the Old World. Fine California olive oils taste as spicy, peppery and pungent as the olives from which they were made.

"California olive oils are not just fats, but are like spices or condiments," says Sonoma County olive oil expert Vossen. "These fine olive oils impart delicious, subtle flavors to food."

With dozens of olive varieties at their disposal, a diversity of climate and soil types, and unconstrained by tradition, California producers are only now beginning to explore the range of flavors that can be coaxed from fine olive oil.

"Flavors range from the green end of the spectrum, with green apple, grass and green tea, to the ripe end, with buttery, nutty and tropical flavors. And they can be found everywhere in between," Flynn says. "Or, you can find all these flavors wrapped up in one very complex olive oil."

\section{- Jeannette Warnert}

\section{Campus trees yield olive oil, body-care products}

UC Davis has been producing olive oil from its more than 2,000 olive trees since 2005, keeping the olives - which used to clutter the ground - out of the waste stream while generating revenue for teaching and research at the UC Davis Olive Center.

The center recently launched its "President's Blend" olive oil, and teamed up with UC Davis alumna Kacie Klein to produce a collection of olive-oil-based bodycare products including lotion, body butter, hand-cut soap and lip balm.

"These new products are all made with olive oil produced by the campus's historic olive trees, using olives and olive oil that would otherwise have gone to waste," says Dan Flynn, executive director of the Olive Center. The product sales support research into new olive cultivars, mechanical harvesting, olive fruit fly control, olive processing

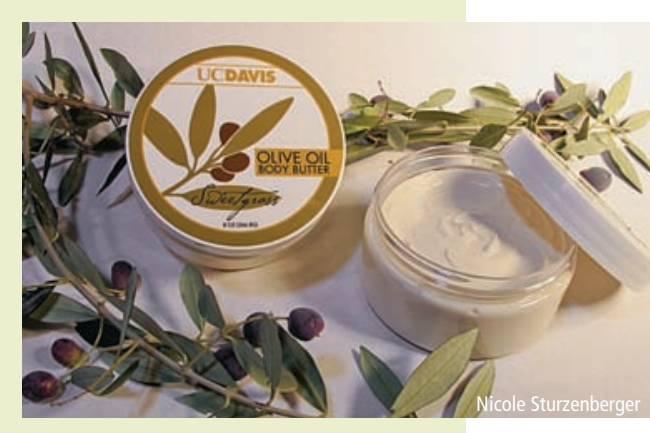

Olives from the UC Davis campus, which once littered the ground, are now used to produce body-care products. and the sensory evaluation of olive oil.

"Olives have the potential to be one of the leading crops in the state, with UC Davis being a leader in the industry, just like with wine and almonds," UC President Mark Yudof said.

UC Davis olive products are sold in the UC Davis Bookstore and can be ordered online from the its "Campus Produced" section at: http://ucdavisbookstore.com/MerchList/ aspx?ID=16472\&CatID=3016. 